\title{
Technical Note: High-resolution mineralogical database of dust-productive soils for atmospheric dust modeling
}

\author{
S. Nickovic ${ }^{1}$, A. Vukovic ${ }^{2,3}$, M. Vujadinovic ${ }^{2,3}$, V. Djurdjevic ${ }^{4,3}$, and G. Pejanovic ${ }^{3}$ \\ ${ }^{1}$ World Meteorological Organization, Geneva, Switzerland \\ ${ }^{2}$ Faculty of Agriculture, University of Belgrade, Serbia \\ ${ }^{3}$ South East European Virtual Climate Change Center, Belgrade, Serbia \\ ${ }^{4}$ Institute of Meteorology, University of Belgrade, Serbia \\ Correspondence to: S. Nickovic (nickovic@gmail.com)
}

Received: 8 September 2011 - Published in Atmos. Chem. Phys. Discuss.: 20 September 2011

Revised: 7 January 2012 - Accepted: 9 January 2012 - Published: 18 January 2012

\begin{abstract}
Dust storms and associated mineral aerosol transport are driven primarily by meso- and synoptic-scale atmospheric processes. It is therefore essential that the dust aerosol process and background atmospheric conditions that drive dust emissions and atmospheric transport are represented with sufficiently well-resolved spatial and temporal features. The effects of airborne dust interactions with the environment determine the mineral composition of dust particles. The fractions of various minerals in aerosol are determined by the mineral composition of arid soils; therefore, a high-resolution specification of the mineral and physical properties of dust sources is needed.

Several current dust atmospheric models simulate and predict the evolution of dust concentrations; however, in most cases, these models do not consider the fractions of minerals in the dust. The accumulated knowledge about the impacts of the mineral composition in dust on weather and climate processes emphasizes the importance of including minerals in modeling systems. Accordingly, in this study, we developed a global dataset consisting of the mineral composition of the current potentially dust-producing soils. In our study, we (a) mapped mineral data to a high-resolution $30 \mathrm{~s}$ grid, (b) included several mineral-carrying soil types in dust-productive regions that were not considered in previous studies, and (c) included phosphorus.
\end{abstract}

\section{Introduction}

Mineral dust is recognized as one of the most abundant aerosols on a global scale. While being transported in the atmosphere, dust modifies the Earth's radiation budget. Dust influences cloud properties and consequently changes at- mospheric stability and circulation (e.g., Todd et al., 2007; Hoose et al., 2008). The relationship between dust and the atmosphere, if included in numerical atmospheric models, could further improve weather forecasts and climate simulations (e.g., Nickovic, 2002, 2004; Perez et al., 2006).

In the 1990s, when the novel concept of incorporating dust concentrations in online atmospheric models was first introduced (Nickovic, 1996; Nickovic and Dobricic, 1996), there was a significant improvement in modeling the process of atmospheric mineral aerosol. Most of these models were designed to simulate and predict the time evolution of the dust concentrations; however, these models typically did not consider the mineral fractions of the dust. Only a few global dust models have included the mineral composition in dust aerosol (Fung et al., 2000; Luo et al., 2005; Hoose et al., 2008), in response to the increased interest of the scientific community in studying the impacts of minerals on the climate and environment.

Despite the progress achieved over the last two decades, considerable uncertainties remain in dust modeling. The results of various regional models have been compared for a dust event lasting several days over the Bodélé depression region (Todd et al., 2008). A similar study was performed over East Asia (Uno et al., 2006). The degree of uncertainty in dust emissions is of an order of magnitude for short simulation periods. The results of a comparison of 15 global aerosol models are also reported in Huneeus et al. (2011). The identified uncertainties would certainly influence the accuracy of the dust mineral composition if it were incorporated into dust models.

Increasing the resolution of atmospheric dust models should help reduce the errors of numerical simulations. There are several components of the atmospheric dust 
process characterized by a small-scale nature; one of these small-scale components, dust emissions, is related to topographic depressions (Prospero et al., 2002; Ginoux et al., 2001). Engelstaedter and Washington (2007) identified more than one hundred dust hotspots on a global scale with a high annual correlation with gustiness, a measure of the magnitude of short-lived high wind events that require a highresolution model simulation to be properly reproduced. At the local scale, the complexity of the sources increases. Dust storms can begin as a process of numerous dust plumes emitted from individual point-like sources that then spread and merge into a wide dust veil (Lee et al., 2009). In addition, dust sources constitute only a small fraction of the larger region if most of the region did not experience erosion. Dust transport driven by a low-level wind jet (e.g., Knippertz and Todd, 2007; Washington et al., 2006a,b; Bouet et al., 2007) is another mesoscale process. Furthermore, mineral fractions in dust critically depend on the size of the dust particles emitted into the atmosphere. For studying the long-range transport of dust and minerals embedded in the atmosphere, it is sufficient to consider finer, longer-life particles originating from clay- and silt-sized fractions of soils (e.g., Tegen and Lacis, 1996; Nickovic, 2004). Several dust models have been developed over regional domains using higher spatial resolutions (e.g., Nickovic, 2001; Grini et al., 2005; Tegen et al., 2006; Bouet et al., 2007; Washington et al., 2006a,b; Menut et al., 2007) to better represent smaller-scale features of the dust process. In a recent simulation of the haboob-like dust storms in the southwest of the United States, a $3.5 \mathrm{~km}$ dust model was used to resolve the high-resolution distribution of the point-like dust sources (Vukovic et al., 2011).

Simulating mineral fractions in mesoscale dust atmospheric models requires specifying the geographic distribution of minerals in dust-productive soils at a high resolution (Nickovic and Barrie, 2009). In Sect. 2 of this paper, we discuss the importance of minerals to different processes, including dust minerals interacting with atmospheric processes, their role in the marine environment, and the impacts of minerals on human health. Section 3 describes a new high-resolution gridded database for minerals in potential dust-productive soils developed to support numerical models that simulate the atmospheric transport of mineral components in dust. Following Claquin et al. (1999), we concentrate on soil populations of clay- and silt-sized particles and develop a Mineralogical Table (MT) that establishes a correspondence between different dust-productive soil types following the FAO74 classification (FAO-UNESCO, 1974) with mineral fractions of quartz, feldspar, calcite, gypsum, illite, kaolinite, smectite and hematite. We extended the MT of Claquin et al. (1999) with three new soil types: Yermosols, Haplic Yermosols and Xerosols, which contain considerable amounts of clay- and silt-sized particles. Furthermore, we included phosphorus because of its important role in ocean primary production and land fertilization. Finally, we describe in detailed steps the development of a global database (called GMINER30) mapped onto a $30 \mathrm{~s}$ resolution global grid. The developed database, which presents a mean global evaluation of soil mineral composition, is recommended to be used in models for global and regional studies because high variability on a small scale cannot be supported by the information and methodology used in the preparation of this dataset.

\section{Impacts of mineral aerosols}

The composition of dust minerals affects various processes, such as processes in atmospheric, ocean and terrestrial environments, and also affects human health. Including mineral dust transport interacting with the atmosphere in numerical models can improve the accuracy of weather forecasts and climate simulations and contribute to a better understanding of the environmental processes caused by mineral dust. Below, we elaborate on several impacts of dust in which its mineral composition plays an important role.

\subsection{Minerals and solar radiation}

Mineral dust directly affects atmospheric radiation (Sokolik and Toon, 1999), and consequently atmospheric dynamics (e.g., Nickovic, 2002, 2004; Perez et al., 2006; Helmert et al., 2007), by modifying the incoming solar radiation and the outgoing infrared radiation. As shown in several case studies (e.g., Perez et al., 2006; Todd at al., 2007), the radiative response to a large dust load leads to a reduction by several degrees in the surface daytime temperature maximum.

The response of solar radiation to dust depends on the dust mineral composition. The mineral composition substantially changes the amplitude of the radiative forcing of the dust in both solar and infrared spectra (Sokolik et al., 1998; Claquin et al., 1999; Balkanski et al., 2007). Regarding the radiative impacts caused by mineral composition, the differences between the refractive indices of aluminosilicates (illite, kaolinite, smectite and feldspars) are not significant when compared with their natural variability. Claquin et al. (1999) estimated a global distribution of single-scattering albedo and a ratio of the visible to infrared ratio of the extinction coefficients as a function of mineral composition, indicating the importance of using this information in atmospheric dust models to appropriately represent the atmospheric radiation balance.

\subsection{Minerals and cloud ice nucleation}

Dust aerosol impacts the climate and the environment through its influence on heterogeneous ice nucleation. For example, Klein et al. (2010) found that mineral dust is a dominant constituent in the ice-nucleating process using in-situ measurements of aerosol and observed a high correlation between ice nuclei numbers and simulated dust concentration originating from a major Saharan dust intrusion into Europe. 
In the ice nucleation process, the mineralogical structure of dust plays an important role. Clay minerals in dust are particularly efficient for ice nucleation processes, as shown in field and modeling studies (Chen et al., 1998; Pruppacher and Klett, 1977; Zimmermann et al., 2008, and references therein). Recent studies (e.g., Lohmann and Diehl, 2006; Hoose et al., 2008) have parameterized cold cloud formation as a process in which ice nucleation depends on the mineral composition of dust.

\subsection{Minerals and ocean productivity}

Minerals carried by dust particles and deposited over remote ocean regions after long-term atmospheric transport can provide important nutrients for marine life. Iron, phosphorus and silicon embedded in dust are considered major potential micronutrients for ecosystems in remote oceans.

Singh et al. (2008) showed that in a number of major dust deposition episodes over the Arabian Sea, chlorophyll blooming was detected several days after major dust storm intrusions. Cooling of the ocean surface was also observed, along with higher ocean wind speeds during the dust events, which could create favorable conditions for blooming.

The deficiency of iron limits primary marine productivity and can lead to high-nutrient, low-chlorophyll marine conditions (e.g., Mahowald et al., 2009). Although the iron input into the ocean by rivers is large, it affects only the biota of the coastal zones. However, the deposition of mineral dust in remote oceans after long-range dust transport is considered as a likely source of iron in these regions. Mahowald et al. (2010) showed that iron input into the ocean not only increases ocean productivity but also represents a carbondioxide sink, which has a global warming offsetting effect. It is assumed that the availability of iron to photosynthetic marine microorganisms depends on the iron aerosol solubility. Iron in desert soils is essentially non-soluble, although several cruise-based observations indicate that the solubility increases during aerosol transport (Baker and Jickells, 2006). Factors such as the mineralogy of sources, atmospheric (photo-) chemical processing and particle-sized features are among the most frequently proposed hypotheses (Baker and Croot, 2008). Journet et al. (2008) indicated that iron solubility is linked to the mineralogical composition of the aerosol. According to their study, the most bioavailable fraction of iron in dust is clay minerals containing a relatively low iron content, although more than $90 \%$ is in a soluble form rather than in iron oxides (e.g., hematite), which are characterized by high iron content $(50-80 \%)$. The atmospheric processing of iron on its path from sources to remote oceans, however, remains poorly understood (Mahowald et al., 2009; Okin et al., 2011).

Phosphorus is another marine nutrient embedded in mineral dust that enters into the ocean through atmospheric deposition. Although amounts received by deposition are much smaller than those that enter through river and marine up- welling inputs, this input still might be a significant source of phosphorus in oligotrophic parts of the ocean. Atmospheric phosphorus exists almost entirely in the form of aerosols caused by the low volatility of phosphorus compounds (Mahowald et al., 2005). Both iron and phosphorus inputs influence the nitrogen flux into the ocean. In the presence of sufficient $\mathrm{Fe}$ and $\mathrm{P}$ deposits, the growth of non-diazotrophic organisms might be stimulated (Okin et al., 2011).

Finally, dissolved silicon arriving into the ocean with dust provides a major control on the growth of siliceous phytoplankton in open sea regions. As in the case of iron and phosphorus, riverine input is the major source of silicon in coastal zones, but the atmospheric deposition of silicon carried by soil dust is the most important supplier of this element in remote seas (Tegen and Kohfeld, 2006).

\subsection{Minerals and health}

Airborne dust can significantly influence human health. Middleton et al. (2008) reported an increased number of patient hospitalizations during dust storms in Cyprus. Liu et al. (2009) estimated the impacts of inter-continental transport of aerosols on premature mortality and found that nearly 380 thousand premature deaths per year globally are associated with exposure to fine aerosols that are transported intercontinentally and are composed mostly of dust. Yoshida et al. (2008) found that inhaled desert dust causes adverse effects on the mouse male reproductive function and hypothesized that humans might experience similar effects.

Iron-catalyzed free radical generation is known to be an important factor that enhances acute lung inflammation (Prospero, 1999), and it is also a major carcinogenic factor (Fubini and Arean, 1999). In lungs exposed to mineral aerosol, the probability of oxidative damage is high because of the high oxygen concentration and the presence of catalytically active iron in atmospheric particulates. Iron in the lung can be used for microbial growth and replication, resulting in more virulent and persistent infections (Turi et al., 2004). The rate of reaction between oxygen and ferrous iron in goethite mineral present in dust is particularly high (Schoonen et al., 2006).

Meningococcal (epidemic) meningitis in the Sahel, one of the most serious diseases in Africa, with a high mortality rate, is highly correlated with dusty weather. How dust eventually triggers the meningitis epidemics remains unclear. Thompson et al. (2009) identified dust-related mechanisms as possible epidemic activators, including the impact of dust particles on the fluid dynamics of the airborne transmission of the meningococcal bacteria, the impact of dust on a preceding viral infection, or the activation of meningococcal bacteria through the high iron content of dust particles. 


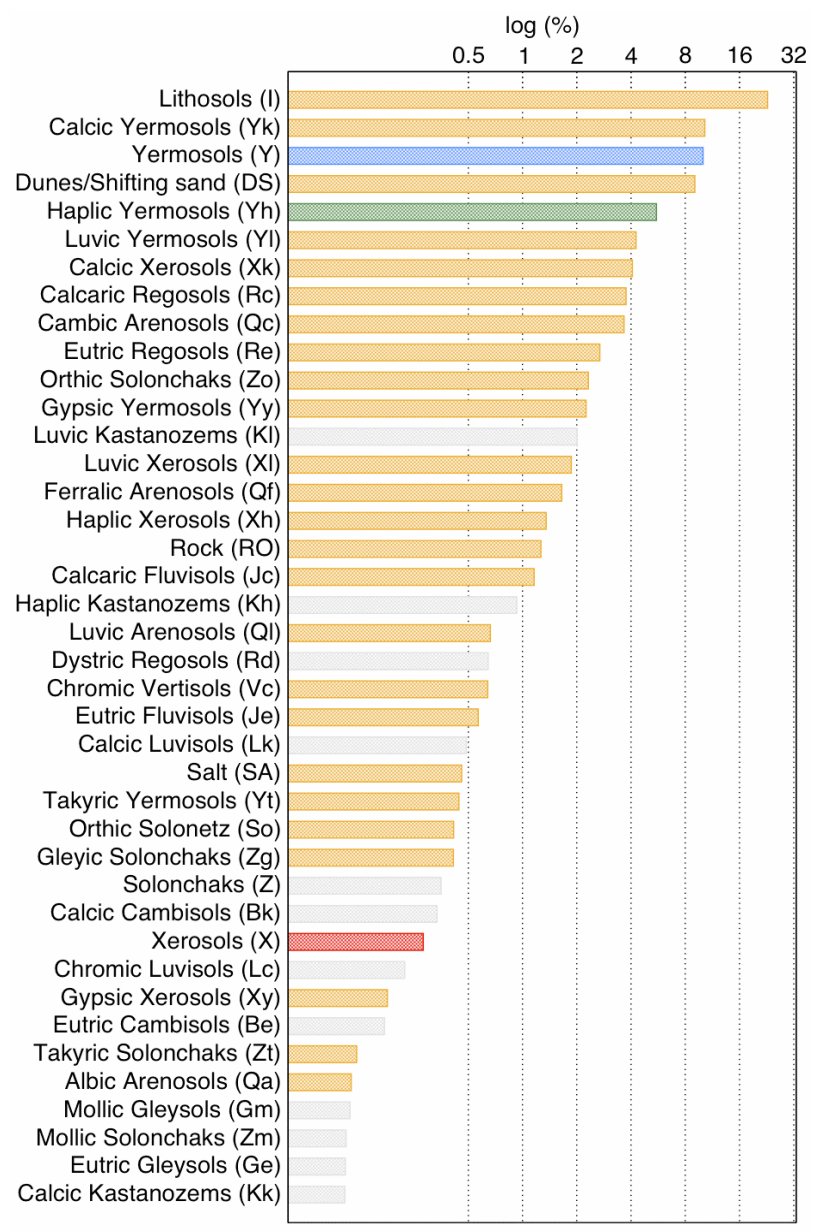

Fig. 1. Fractions of the most common soil types that, in total, cover $99 \%$ of the area of the arid and bare regions on Earth. Orange denotes the soil types introduced in the MT by C99. Blue, green and red bars denote the new, added soil types in the MT. Gray denotes the soil types not included in MT.

\section{Global distribution of minerals}

Soil fractions that contain fine particles (clay and silt with particle sizes less than $0.002 \mathrm{~mm}$ and between 0.002 and $0.05 \mathrm{~mm}$, respectively, according to the United States Department of Agriculture (USDA) Soil Texture Classification system) are lifted from the Earth's surface by a complex process of wind erosion (e.g., Tegen et al., 2002) and then transported downwind. However, the value $0.002 \mathrm{~mm}$, which delineates the size between mineral contents in clay- and silt-sized particles, could be thought of as arbitrary and is used here as a first-order approximation. During its residence in the atmosphere, wind-born dust can significantly impact the environment. Long-range transport and deposition far from the source are driven by atmospheric processes. Atmospheric dust models do simulate such processes but generally do not consider mineral composition in dust, primarily because of the lack of detailed information on the geographic distribution of mineral fractions in dust soil sources. A necessary condition for including mineral composition in models is to provide a gridded database of mineral composition in dustproductive soils.

\subsection{Dust-productive soils}

To identify the FAO (Food and Agriculture Organization of the United Nations) soils that are dust productive, we first identified which soil types occupy the majority of the arid regions on a global scale. We determined such regions using the following Olson land cover categories (Olson, 1994a, b) of the USGS (United States Geological Survey) global dataset: low sparse grassland (considered only in China and Mongolia), bare desert, semi desert, sand desert, semi desert shrubs and semi desert sage. Global distributions of these land cover types include all major dust-productive areas (Engelstaedter and Washington, 2007). The next step was to determine which FAO soil types are the most representative in the selected bare and arid regions. We remapped the FAO 2 min data (FAO-UNESCO, 1992) onto the $30 \mathrm{~s}$ grid to use the same grid as the USGS land cover. By overlapping these two matrices, we obtained fractions of the soil types in the selected land cover categories and found that most of the area, approximately $99 \%$, is dominated by the soil types presented in Fig. 1, in which the fractions of the particular soils range between 0.1 and $23 \%$ of the total area. The soil types listed in Fig. 1 are assumed to be dust productive.

\subsection{Mapping mineral fractions}

Following Claquin et al. (1999), we selected quartz, feldspars, illite, kaolinite, smectite, calcite, gypsum and hematite, for which fractions will be specified for the different soil types. We summarize below the arguments used by Claquin et al. (1999) to select the eight minerals.

The clay phyllosilicates group (illite, kaolinite and smectite) represents the most abundant chemical-weathering minerals in sedimentary rocks. Tectosilicates (quartz, feldspar), based on silicates, together with phyllosilicates, constitute approximately $90 \%$ of the Earth's crust. Because of the presence of aluminum in phyllosilicates and feldspars, these two groups absorb less infrared radiation than does quartz. Finally, phyllosilicates, in comparison with tectosilicates, have larger surface-to-volume area and are therefore more chemically reactive (Norrish and Pickering, 1983).

Carbonates were considered in Claquin et al. (1999) because of their important role in direct and indirect effects on solar radiation; they have a low infrared absorption, between 8 and $12 \mu \mathrm{m}$. Carbonates are not highly soluble in water, but they are the most reactive component of mineral dust in an acidic environment, suggesting that carbonates in dust influence the precipitation acidity, act as cloud condensation nuclei and therefore contribute to indirect radiation effects. 
Table 1. Mineral content in clay and silt-sized fractions in selected soil types.

\begin{tabular}{|c|c|c|c|c|c|c|c|c|c|c|c|c|}
\hline \multirow{2}{*}{$\begin{array}{l}\text { FAO soil types } \\
\text { in arid regions }\end{array}$} & \multicolumn{6}{|c|}{ Mineral content in clay-sized fractions normalized to $100 \%$} & \multicolumn{5}{|c|}{ Mineral content in silt-sized fraction normalized to $100 \%$} & \multirow{2}{*}{$\begin{array}{l}\text { Clay and silt } \\
\text { Phosphorus }^{\mathrm{a}}\end{array}$} \\
\hline & Illite & Kaolinite & Smectite & Calcite & Quartz & Hematite $^{b}$ & Feldspar & Gypsum & Calcite & Quartz & Hematite $^{b}$ & \\
\hline Lithosols (I) & 40 & 20 & 29 & 4 & 7 & 1 & 40 & 1 & 6 & 53 & 1 & 0.049 \\
\hline Calcic Yermosols (Yk) & 57 & 13 & 16 & 11 & 3 & 2 & 7 & 1 & 14 & 78 & 2 & 0.031 \\
\hline Yermosols $(\mathrm{Y})^{\mathrm{a}}$ & 34 & 31 & 24 & 6 & 5 & 1 & 32 & 2 & 8 & 59 & 1 & 0.031 \\
\hline Dunes/Shifting Sand (DS) & 50 & 9 & 26 & 1 & 14 & 1 & 6 & 1 & 1 & 92 & 1 & - \\
\hline Haplic Yermosols $(\mathrm{Yh})^{\mathrm{a}}$ & 20 & 54 & 22 & 1 & 3 & 2 & 24 & 1 & 1 & 73 & 2 & 0.031 \\
\hline Luvic Yermosols (Yl) & 45 & 20 & 20 & 7 & 7 & 2 & 23 & 1 & 5 & 70 & 2 & 0.031 \\
\hline Calcic Xerosols (Xk) & 57 & 13 & 16 & 11 & 3 & 2 & 7 & 1 & 14 & 78 & 2 & 0.034 \\
\hline Calcaric Regosols (Rc) & 42 & 39 & 9 & 4 & 7 & 3 & 19 & 1 & 3 & 75 & 3 & 0.049 \\
\hline Cambic Arenosols (Qc) & 16 & 66 & 5 & 1 & 11 & 4 & 14 & 1 & 1 & 82 & 4 & 0.04 \\
\hline Eutric Regosols (Re) & 32 & 53 & 10 & 1 & 5 & 2 & 38 & 1 & 1 & 59 & 2 & 0.049 \\
\hline Othic Solonchaks (Zo) & 31 & 6 & 46 & 11 & 7 & 1 & 43 & 6 & 22 & 31 & 1 & 0.034 \\
\hline Gypsic Yermosols (Yy) & 27 & 18 & 40 & 8 & 7 & 0 & 26 & 6 & 16 & 57 & 0 & 0.031 \\
\hline Luvic Xerosols (X1) & 45 & 20 & 20 & 7 & 7 & 2 & 23 & 1 & 5 & 70 & 2 & 0.034 \\
\hline Ferralic Arenosols (Qf) & 23 & 48 & 23 & 1 & 5 & 1 & 15 & 1 & 1 & 84 & 1 & 0.04 \\
\hline Haplic Xerosols (Xh) & 20 & 54 & 22 & 1 & 3 & 2 & 24 & 1 & 1 & 73 & 2 & 0.034 \\
\hline Rock (RO) & 50 & 9 & 26 & 1 & 14 & 1 & 6 & 1 & 1 & 92 & 1 & - \\
\hline Calcaric Fluvisols (Jc) & 22 & 9 & 46 & 11 & 12 & 0 & 39 & 2 & 30 & 31 & 0 & 0.03 \\
\hline Luvic Arenosols (Q1) & 10 & 78 & 3 & 1 & 9 & 3 & 22 & 1 & 1 & 70 & 5 & 0.04 \\
\hline Chromic Vertisols (Vc) & 16 & 27 & 48 & 4 & 5 & 4 & 62 & 1 & 3 & 31 & 4 & 0.079 \\
\hline Eutric Fluvisols (Je) & 18 & 23 & 55 & 1 & 3 & 1 & 10 & 1 & 2 & 86 & 1 & 0.03 \\
\hline Salt (SA) & 39 & 4 & 26 & 29 & 1 & 1 & 1 & 26 & 93 & 5 & 1 & - \\
\hline Takyric Yermosols (Yt) & 21 & 51 & 21 & 3 & 5 & 1 & 80 & 1 & 4 & 16 & 1 & 0.031 \\
\hline Orthic Solonetz (So) & 37 & 32 & 17 & 6 & 7 & 2 & 23 & 1 & 4 & 71 & 2 & 0.022 \\
\hline Gleyic Solonchaks (Zg) & 16 & 32 & 24 & 21 & 5 & 0 & 28 & 15 & 20 & 51 & 0 & 0.034 \\
\hline Xerosols $(\mathrm{X})^{\mathrm{a}}$ & 37 & 26 & 24 & 7 & 5 & 2 & 20 & 2 & 9 & 70 & 2 & 0.031 \\
\hline Gypsic Xerosols (Xy) & 27 & 18 & 40 & 8 & 7 & 0 & 26 & 6 & 16 & 57 & 0 & 0.034 \\
\hline Takyric Solonchaks (Zt) & 25 & 33 & 24 & 10 & 6 & 0 & 66 & 1 & 12 & 22 & 0 & 0.034 \\
\hline Albic Arenosols (Qa) & 21 & 53 & 21 & 0 & 4 & 1 & 15 & 1 & 0 & 84 & 1 & 0.04 \\
\hline
\end{tabular}

a Mineral content added in this paper as an extension to the mean mineralogy table from Claquin et al. (1999). ${ }^{\text {b }}$ Hematite represents total hematite and goethite content.

Gypsum originates mainly from (paleo-) lacustrine sources and has moderate absorption in the infrared spectrum. The importance of lacustrine sources for dust emissions has been emphasized by Tegen et al. (2002), who introduce lacustrine sources as a separate soil texture class.

Mineral fractions are distributed over clay- and silt-sized particle populations, as shown in Table 1. Note that calcite, quartz and hematite appear in both populations. Following Claquin et al. (1999), hematite and goethite are considered together using a common name, hematite. From Fig. 1, it is obvious that 25 soil types selected in Claquin et al. (1999), marked in orange, occupy the major part of the potential dust-productive area, with two additional soil types, which appear in high percentages, Yermosols (10\%) and HaplicYermosols $(5.5 \%)$.

To determine the effective fractions of minerals in soils, the percentages of clay- and silt-sized particles have to be specified. Because there is no corresponding global data for specific soils, these fractions are evaluated using the hybrid STATSGO (State Soil Geographic Database) - FAO soil map (US Department of Agriculture, 1994) available in a 30 s resolution for 12 USDA soil texture classes. Clay and silt percentages in the soil texture classes are specified using Table 1 from Shirazi et al. (2001) and modified following the approach by Tegen et al. (2002), in which because loamy sands tend to contain aggregated clay particles, a clay fraction is added to silt. By overlapping the STATSGO-FAO and FAO data, we calculated the mean global percentages of the clayand silt-sized particles for the soil types in Fig. 1. The results are shown in Fig. 2. Yermosols (Y) and HaplicYermosols (Yh) contain $12 \%$ and $14 \%$ of clay and $31 \%$ and $32 \%$ of silt, respectively. The high content of silt and clay in these two soils qualifies them to be included in further analyses.

The mineral composition for Haplic Yermosols (Yh) is assumed to have the same mineral composition as Haplic Xerosols $(\mathrm{Xh})$, following the analogy proposed by Claquin et al. (1999). The mineral composition for Yermosols (Y) is assumed to be equal to the mean of the fractions of the $Y$ group, i.e., Yk, Yh, Yl, Yy and Yt. Xerosols (X) occupy only $0.3 \%$ of the potential dust-productive areas (Northwest Africa and Central Asia) but have an average content of $19 \%$ clay and $40 \%$ silt and could therefore have a great influence on the composition of the mineral aerosol. We also added $\mathrm{X}$, with its mineral composition obtained as a mean of the mineral content of other soils of the Xeroslols group (i.e., $\mathrm{Xk}, \mathrm{Xh}, \mathrm{Xl}$, $\mathrm{Xy}$ ), as presented in Claquin et al. (1999). The global distribution of soil types introduced by Claquin et al. (1999) and the additional three soil types, $\mathrm{Y}, \mathrm{Yh}$ and $\mathrm{X}$, are presented in Fig. 3. Note that, as reported by Claquin et al. (1999), the values for the mineral fractions are global mean values with standard deviations ranging from $27 \%$ to $33 \%$. The list of minerals in the MT is extended with phosphorus because of its importance in the primary marine and terrestrial nutrient supply. Although only a small part of the phosphorus 


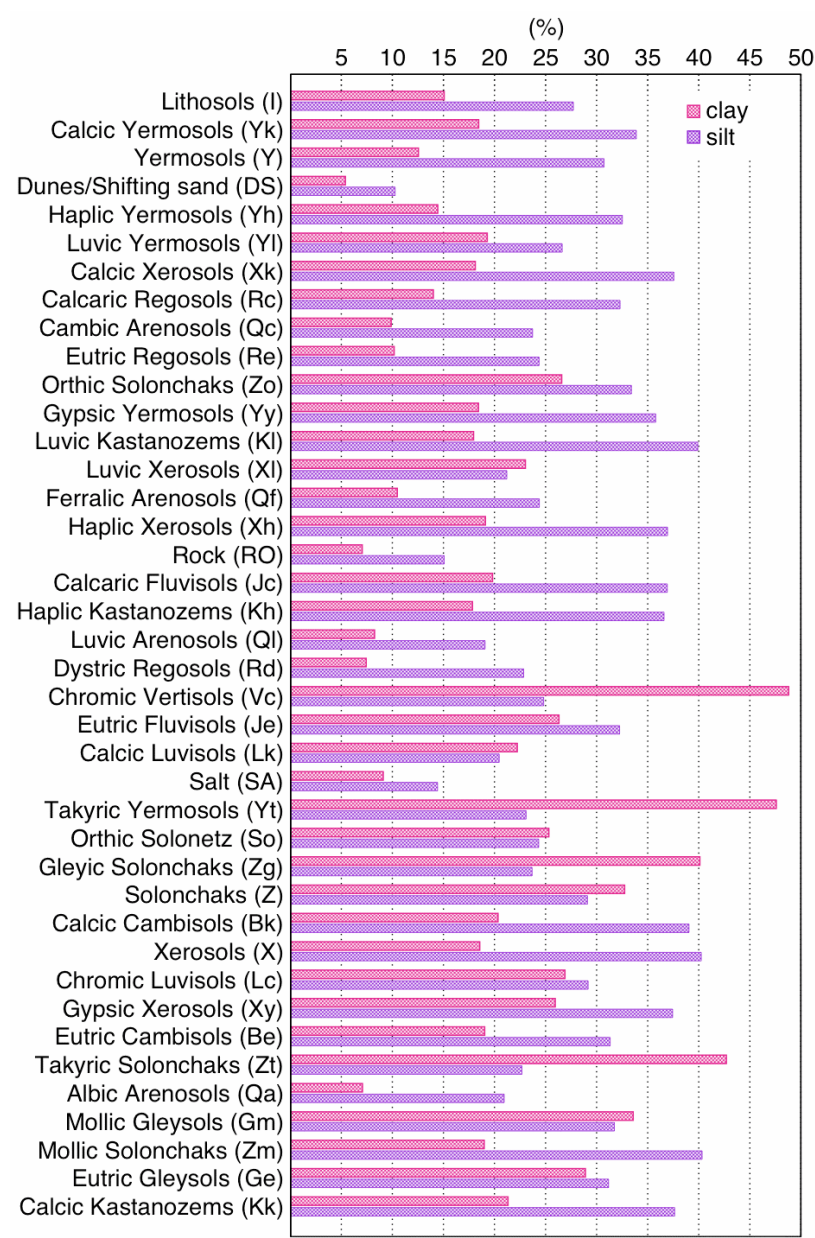

Fig. 2. Global mean fractions of clay and silt for soil types listed in Fig. 1.

in mineral dust aerosol is bioavailable (Jickells and Spokes, 2001; Mahowald et al., 2005), it may play an important role in the biological response of the marine ecosystem when dust is deposited into the ocean. Okin et al. (2004) linked phosphorus concentrations to the top $20 \mathrm{~cm}$ of the 12 USDA (United States Department of Agriculture National Resource Conservation Service) soil categories. To be consistent with the MT, we matched USDA soil orders and FAO soil classes that we assumed to be potential dust-productive areas (Fig. 1) and used information about the typical bulk density of soils from Rawls (1983). The data on the phosphorus content are available only for general soil classes and are not considered separately for clay and silt populations. In the absence of more detailed information, we assumed that all of the soil types that belong to the same group have the same phosphorus content. The results are given in percentages common for both clay- and silt-sized particles.

By compiling data from the steps described above, in Table 1 , we derived the percentages of 9 minerals in clayand silt-sized particles for 28 FAO soil types, which are listed in their order of appearance in Fig. 1. Based on the mineral fractions in Table 1 , we created a global $30 \mathrm{~s}$ gridded dataset of mineral composition called GMINER30. The data are organized in geographic sub-domains (tiles) as used in the USGS topography dataset. In our study, we used only tiles north of $60^{\circ} \mathrm{S}$. In total, the database consists of 324 files (27 tiles for 12 minerals in silt and clay, see also Fig. 2s in Supplement). GMINER30 is available at http://www.seevccc.rs/GMINER30/. The database contains a mean global distribution of the soil mineral composition appropriate for implementation in models for global and regional studies. A high variation in soil composition, for example, in the Bodélé depression (Bristow et al., 2010), is not expected to be properly resolved by this database, and it is also beyond the scope of any potential atmospheric dust model simulations discussed here. Introducing information regarding the dust mineral composition obtained from the database, despite the uncertainties originating from scarce soil sampling, is expected to provide additional important information to better understand the role of minerals in atmospheric dust processes.

The soil composition is set equal to an atmospheric dust composition; however, the transfer function is not unity (Eltayeb et al., 2001). The quantification of minerals in aerosol samples is not straightforward, mostly because the amounts of aerosol mass collected downwind are small. Several authors have therefore assumed that the aerosol mineral content is the same as in source soils (Claquin et al., 1999). Furthermore, Caquineau et al. (1998) have shown that the relative proportions of clay minerals in the aerosol are close to those of the parent soils and are conserved during transport. The same argument was reported by Lafon et al. (2004). For practical implementation of the GMINER30 data in an atmospheric-dust model, effective mineral fractions have to be specified by multiplying a fraction of a particular mineral with its corresponding clay and silt fraction in the soil. In the example shown in Fig. 4, we calculated the distribution of effective mineral contents using the GMINER30 fractions multiplied by the clay and silt contents from the hybrid STATSGO-FAO dataset.

Silicates have the highest content when compared with the other considered minerals (Fig. 4a-e, see also Fig. 1s in Supplement). The quartz content (Fig. 4a) is larger than $12 \%$ over almost the entire area where the selected soil types are found (Fig. 2), with high contents (over $30 \%$ ) on every continent. Illite, kaolinite and smectite (Fig. 4b-d), which are present only in clay populations, generally have concentrations up to $12 \%$. An exception is illite in the Middle East, with values greater than $20 \%$ and maximums greater than $25 \%$. The maximums of kaolinite and smectite concentrations are collocated in several regions, such as in Eastern Africa, Western India and East Australia. Kaolinite reaches a maximum of $16 \%$, whereas the smectite maximum is greater than $28 \%$. The surface content of feldspar (Fig. 4e) is characterized by strong gradients, particularly in Central Sahara, 


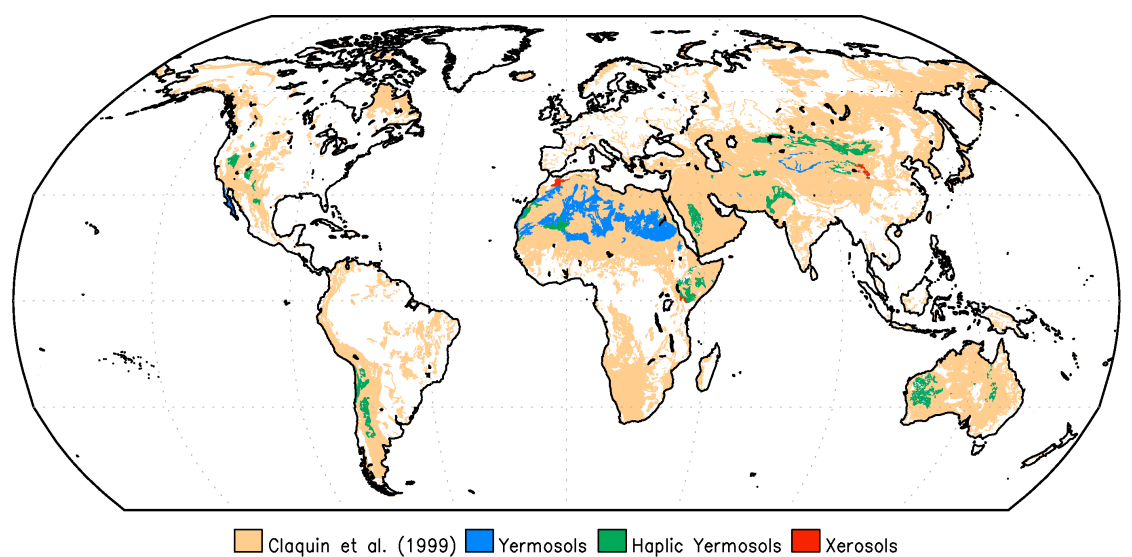

Fig. 3. Global distribution of the soil types selected by Claquin et al. (1999) with three new selected soil types: Yermosols, Haplic Yermosols and Xerosols.
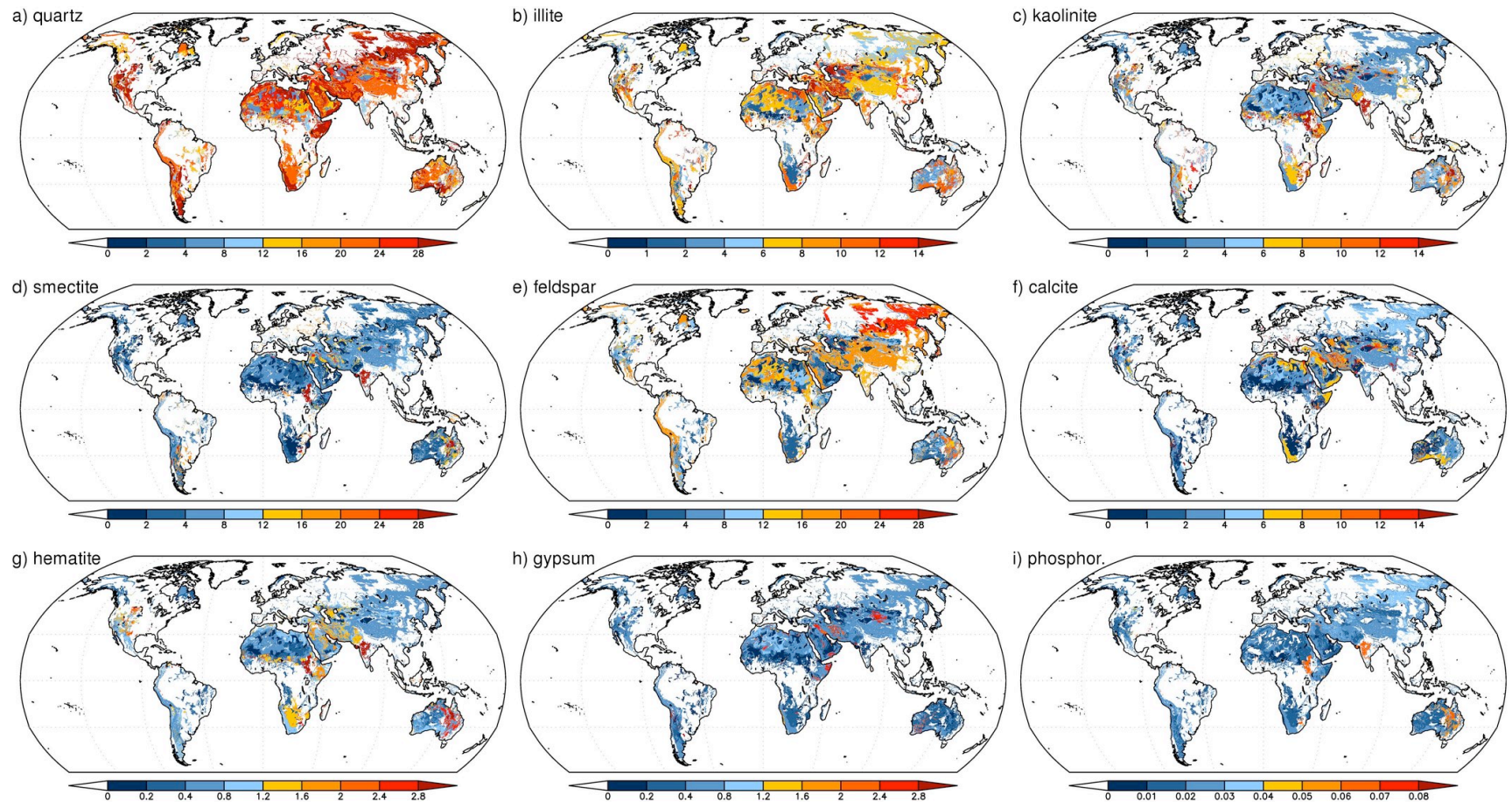

Fig. 4. Global distribution of the effective mineral content in soil in percentages for (a) quartz, (b) illite, (c) kaolinite, (d) smectite, (e) feldspar, (f) calcite, (g) hematite, (h) gypsum and (i) phosphorus. The mineral fraction is weighted with the clay and silt content in soil. For minerals that are present in both clay and silt, the weighted values are summed.

with maximum values greater than $16 \%$ and surrounded by areas with values less than $2 \%$. Asia has the highest feldspar content, with maxima ranging from $24 \%$ to $28 \%$. Carbonate mineral calcite (Fig. 4f) is present in both silt and clay populations, with a content generally less than $6 \%$. Higher values can be found in South Africa, the Mediterranean coast of Africa, South Australia, Arabia and the Middle East. The iron oxide (Fig. 4g) content is lower than in other minerals, with contents less than $3 \%$ on a global scale. Sulfate mineral gypsum (Fig. 4h) is present only in the silt populations, with amounts less than $1 \%$. Smaller areas with maxima greater than $2 \%$ are located in Africa, Arabia and Asia. Phosphorus (Fig. 4i) has maximums that do not exceed $0.07 \%$.

Not all of the areas covered in GMINER30 and in Figs. 3 and 4 are necessarily dust-productive areas. The next step is to overlap the mineral data with a dust mask. Dustatmospheric models use different approaches in mapping dust source regions. Often, the first guess in defining dust- 
productive areas is made based on USGS Global Land Cover Data (Nickovic et al., 2001; Walker et al., 2008), which usually implies a selection of land cover types that are barren and arid and thus potentially dust-productive areas. Another approach is to assume that such regions coincide with arid regions receiving a long-term average of precipitation lower than a threshold (Claquin et al., 1999). Dust-productive areas can be identified by defining dust preferential sources based on topographic features of the terrain (Ginoux et al., 2001), hydrology paths (Tegen et al., 2002), geomorphological features (Zender et al., 2003), and satellite observations (Prospero et al., 2002); a seasonal dependence was considered by Tegen et al. (2002).

\section{Summary and conclusions}

There has been increasing attention from the scientific community regarding the dust mineral composition interactions with the environment. Recently, the Joint Workshop of GESAMP and the WMO Sand and Dust Storm Warning Advisory and Assessment System (SDSWAS) on Modeling and Observing the Impacts of Dust Transport/Deposition on Marine Productivity (WMO, 2011) emphasized the importance of the "use of high-resolution soil mineralogical maps for modeling dust production and simulating 3-D transport and transformation of different minerals as a result of atmospheric processing, including the process of Fe-solubility".

Because of the lack of sufficiently resolved information on the mineral content in sources, the current dust numerical models either poorly simulate or do not simulate the ways in which mineral fractions evolve and transform during atmospheric transport. The objective of our study was to improve the information on the geographic distribution of mineral content in arid soils on a global scale. For that purpose, we developed a database of soil minerals mapped on a $30 \mathrm{~s}$ grid (GMINER30). GMINER30 is based on the mineral table specified by Claquin et al. (1999), which we have upgraded by including three additional FAO soil types (Yermosols, Haplic Yermosols and Xerosols) found to exist in major dust-productive areas. We also supplemented the table with phosphorus fractions in soils. When applied in atmospheric dust models, the GMINER30 data should be used to specify the emissions of mineral fractions in potential dustproductive soils.

In our study, we did not consider agricultural soils that could be significant seasonal sources of dust. These soils, as well as the development of a dust atmospheric model that includes the simulation of mineral fractions, will be subjects for future work.

\section{Supplementary material related to this article is available online at: http://www.atmos-chem-phys.net/12/845/2012/ acp-12-845-2012-supplement.pdf.}

Acknowledgements. We would like to thank Richard L. Reynolds and Harland Goldstein (USGS) for their helpful comments. This study was conducted under research project III 43007 supported by the Serbian Ministry of Science and Technological Development. The contributions of the first author were performed as non-funded work outside of his official duties with the World Meteorological Organization (WMO), and the contents of this study do not necessarily express the views of the WMO.

Edited by: C. Hoose

\section{References}

Baker, A. R. and Croot, P. L.: Atmospheric and marine controls on aerosol iron solubility in seawater, Mar. Chem., 120, 4-13, doi:10.1016/j.marchem.2008.09.003, 2008.

Baker, A. R. and Jickells, T. D.: Mineral particle size as a control on aerosol iron solubility, Geophys. Res. Lett., 33, L17608, doi:10.1029/2006GL026557, 2006.

Balkanski, Y., Schulz, M., Claquin, T., and Guibert, S.: Reevaluation of Mineral aerosol radiative forcings suggests a better agreement with satellite and AERONET data, Atmos. Chem. Phys., 7, 81-95, doi:10.5194/acp-7-81-2007, 2007.

Bouet, C., Cautenet, G., Washington, R., Todd, M. C., Laurent, B., Marticorena, B., and Bergametti, G.: Mesoscale modeling of aeolian dust emission during the BoDEx 2005 experiment, Geophys. Res. Lett., 34, L07812, doi:10.1029/2006GL029184, 2007.

Bristow, C. S., Hudson-Edwards, K. A., and Chappell, A..: Fertilizing the Amazon and equatorial Atlantic with West African dust, Geophys. Res. Lett., 37, L14807, doi:10.1029/2010GL043486, 2010.

Caquineau, S., Gaudichet, A., Gomes, L., Magonthier, M.-C. and Chatenet, B.: Saharan dust: clay ratio as a relevant tracer to assess the origin of soil-derived aerosols, Geophys. Res. Lett., 25, 983-986, 1998.

Chen, Y., Kreidenweis, S., McInnes, L. Rogers, D. C., and DeMott, P. J.: Single particle analyses of ice nucleating aerosols in the upper troposphere and lower stratosphere, Geophys. Res. Lett., 25, 1391-1394, 1998.

Claquin, T., Schulz, M., and Balkanski, Y.: Modeling the mineralogy of atmospheric dust sources, J. Geophys. Res., 104, 2224322256, 1999.

Engelstaedter, S. and Washington, R.: Temporal controls on global dust emissions: The role of surface gustiness, Geophys. Res. Lett., 34, L15805, doi:10.1029/2007GL029971, 2007.

FAO-UNESCO: UNEP Gridded FAO/UNESCO Soil Units. Digital Raster Data on a 2-min Cartesian Orthonormal Geodetic (lat/long) $10800 \times 5400$ grid, in: Global Ecosystems Database Version 2.0. Boulder, CO: NOAA National Geophysical Data Center, 1992.

FAO-UNESCO: Soil Map of the World, 1:5000000, 10 volumes, UNESCO, Paris, France, 1974. 
Fubini, B. and Areán, C. O.: Chemical aspects of the toxicity of inhaled mineral dusts, Chem. Soc. Rev., 28, 373-381, 1999.

Fung, I. Y., Meyn, S. K., Tegen, I., Doney S. C., John, J. G., and Bishop, J. K. B.: Iron supply and demand in the upper ocean, Global Biogeochem. Cy., 14, 281-295, 2000.

Ginoux, P., Chin, M., Tegen, I., Prospero, J., Holben, B., Dubovik, O., and Lin, S. J.: Sources and distributions of dust aerosols simulated with the GOCART model, J. Geophys. Res., 106, 2025520273, 2001.

Grini, A., Myhre, G., Zender, C. S., and Isaksen, I. S. A.: Model simulations of dust sources and transport in the global atmosphere: Effects of soil erodibility and wind speed variability, J. Geophys. Res., 110, D02205, doi:10.1029/2004JD005037, 2005.

Helmert, J., Heinold, B., Tegen, I., Hellmuth, O. and Wendisch, M.: On the direct and semidirect effects of Saharan dust over Europe: A modeling study, J. Geophys. Res., 112, D13208, doi:10.1029/2006JD007444, 2007.

Hoose, C., Lohmann, U., Erdin, R., and Tegen, I.: The global influence of dust mineralogical composition on heterogeneous ice nucleation in mixed-phase clouds, Environ. Res. Lett., 3, 025003, doi:10.1088/1748-9326/3/2/025003, 2008.

Huneeus, N., Schulz M., Balkanski Y., Griesfeller J., Prospero J., Kinne S., Bauer S., Boucher, O., Chin M., Dentener F., Diehl T., Easter R., Fillmore D., Ghan S., Ginoux P., Grini A., Horowitz L., Koch D., Krol M. C., Landing W., Liu X., Mahowald N., Miller R., Morcrette J.-J., Myhre G., Penner J., Perlwitz J., Stier P., Takemura T., and Zender C. S.: Global dust model intercomparison in AeroCom phase I, Atmos. Chem. Phys., 11, 77817816, doi:10.5194/acp-11-7781-2011, 2011.

Journet, K., Desboeufs, V., Caquineau, S., and Colin, J. L.: Mineralogy as a critical factor of dust iron solubility, Geophys. Res. Lett., 35, L07805, doi:10.1029/2007GL031589, 2008.

Jickells, T. D. and Spokes, L. J.: Atmospheric iron inputs to the ocean, in Biogeochemistry of Iron in Seawater, edited by D. Turner and K. A. Hunter, 85-121, John Wiley, Hoboken, N.J., 2001.

Klein, H., Nickovic, S., Haunold,W., Bundke, U., Nillius, B., Ebert, M., Weinbruch, S., Schuetz, L., Levin, Z., Barrie, L. A., and Bingemer, H.: Saharan dust and ice nuclei over Central Europe, Atmos. Chem. Phys., 10, 10211-10221, doi:10.5194/acp10-10211-2010, 2010.

Knippertz, P. and Todd, M. C.: The central west Saharan dust hot spot and its relation to African easterly waves and extratropical disturbances, J. Geophys. Res., 115, D12117, doi:10.1029/2009JD012819, 2010.

Lafon, S., Rajot J. L., Alfaro S. C., and Gaudichet, A.: Quantification of iron oxides in desert aerosol, Atmos. Environ., 38, 12111218, 2004.

Lee, J. A., Gill, T. E., Mulligan, K. R., Dominguez Acosta, M., and Perez, A. E.: Land Use/Land Cover and Point Sources of the 15 December 2003 Dust Storm in Southwestern North America, Geomorphology, 105, 18-27, doi:10.1016/j.geomorph.2007.12.016, 2009.

Liu, J., Mauzerall, D. L., and Horowitz, L. W.: Evaluating Inter-continental transport of fine aerosols: (2) Global Health Impacts, Atmos. Environ., 43, 4327-4338, doi:10.1016/j.atmosenv.2009.05.032, 2009.

Lohmann, U. and Diehl, K.: Sensitivity Studies of the Importance of Dust Ice Nuclei for the Indirect Aerosol Effect on
Stratiform Mixed-Phase Clouds, J. Atmos. Sci., 63, 968-982, doi:10.1175/JAS3662.1, 2006.

Luo, C., Mahowald, N. M., Meskhidze, N., Chen, Y., Siefert, R. L., Baker, A. R., and Johansen, A. M.: Estimation of iron solubility from observations and a global aerosol model, J. Geophys. Res., 110, D23307, doi:10.1029/2005JD006059, 2005.

Mahowald, N. M., Artaxo, P., Baker, A. R., Jickells, T. D., Okin, G. S., Randerson, J. T., and Townsend, A. R.: Impacts of biomass burning emissions and land use change on Amazonian atmospheric phosphorus cycling and deposition, Global Biogeochem. Cy., 19, GB4030, doi:10.1029/2005GB002541, 2005.

Mahowald, N. M., Engelstaedter, S., Luo, C., Sealy, A., Artaxo, P., Benitez-Nelson, C., Bonnet, S., Chen, Y., Chuang, P. Y., Cohen, D. D., Dulac, F., Herut, B., Johansen, A. M., Kubilay, N., Losno, R., Maenhaut, W., Paytan, A., Prospero, J. M., Shank, L. M., and Siefert R. L.: Atmospheric Iron Deposition: Global Distribution, Variability, and Human Perturbations, Annu. Rev. Marine. Sci., 1, 245-278, doi:10.1146/annurev.marine.010908.163727, 2009.

Mahowald, N. M., Kloster, S., Engelstaedter, S., Moore, J. K., Mukhopadhyay, S., McConnell, J. R., Albani, S., Doney, S. C., Bhattacharya, A., Curran, M. A. J., Flanner, M. G., Hoffman, F. M., Lawrence, D. M., Lindsay, K., Mayewski, P. A., Neff, J., Rothenberg, D., Thomas, E., Thornton, P. E., and Zender, C. S.: Observed 20th century desert dust variability: impact on climate and biogeochemistry, Atmos. Chem. Phys., 10, 10875-10893, doi:10.5194/acp-10-10875-2010, 2010.

Menut, L., Foret, G., and Bergametti, G.: Sensitivity of mineral dust concentrations to the model size distribution accuracy, J. Geophys. Res., 112, D10210, doi:10.1029/2006JD007766, 2007.

Middleton, N., Yiallouros, P., Kleanthous, S., Kolokotroni, O., Schwartz, J., Dockery, D. W., Demokritou, P., and Koutrakis, P.: A 10 yr time-series analysis of respiratory and cardiovascular morbidity in Nicosia, Cyprus: the effect of short-term changes in air pollution and dust storms, Environ. Health, 7, 39, 1-16, doi:10.1186/1476-069X-7-39, 2008.

Nickovic, S.: Modelling of dust process for the Saharan and Mediterranean area, in: The impact of African dust across the Mediterranean, edited by: Guerzoni, S., and Chester, R., Kluwer Academic Publishers, Dordrecht, The Netherlands, 15-23, 1996.

Nickovic, S.: Dust Aerosol Modeling: Step Toward Integrated Environmental Forecasting, Eos. Trans. AGU, 83, Fall Meet., A71E-04, 2002.

Nickovic, S.: Interactive Radiation-Dust Model: A Step to Further Improve Weather Forecasts (invited presentation). International Symposium on Sand and Dust Storm, Beijing, China, 12-14 September 2004, 2004.

Nickovic, S. and Barrie, L.: Desert dust impacts on environment: International research cooperation and review of some modelling aspects. International Workshop on Atmospheric Composition Changes: Climate-Chemistry Interactions, Lecce, 2-4 November 2009, 2009.

Nickovic, S. and Dobricic, S.: A model for long-range transport of desert dust, Mon. Weather Rev., 124, 2537-2544, 1996.

Nickovic, S., Kallos, G., Papadopoulos, A., and Kakaliagou, O.: A model for prediction of desert dust cycle in the atmosphere, J. Geophys. Res., 106, 18113-18129, 2011.

Norrish K. and Pickering J.G.: Clay minerals. In: Soils: An Australia viewpoint, Melbourne: CSIRO, London, Academic Pr., 281-308, 1983. 
Okin, G. S., Mahowald, N., Chadwick, O. A., and Artaxo, P.: Impact of desert dust on the biogeochemistry of phosphorus in terrestrial ecosystems, Global Biogeochem. Cy., 18, GB2005, doi:10.1029/2003GB002145, 2004.

Okin, G. S., Baker, A. R., Tegen, I., Mahowald, N. M., Dentener, F. J., Duce, R. A., Galloway, J. N., Hunter, K., Kanakidou, M., Kubilay, N., Prospero, J. M., Sarin, M., Surapipith, V., Uematsu, M. and Zhu, T.: Impacts of atmospheric nutrient deposition on marine productivity: Roles of nitrogen, phosphorus, and iron, Global Biogeochem. Cy., 25, GB2022, doi:10.1029/2010GB003858, 2011.

Olson, J. S.: Global ecosystem framework-definitions: USGS EROS Data Center Internal Report, Sioux Falls, SD, 37 pp., 1994a.

Olson, J. S.: Global ecosystem framework-translation strategy: USGS EROS Data Center Internal Report, Sioux Falls, SD, 39 pp., 1994b.

Pérez, C., Nickovic, S., Pejanovic, G., Baldasano, J. M., and Özsoy, E.: Interactive dust-radiation modeling: A step to improve weather forecasts, J. Geophys. Res., 111, D16206, doi:10.1029/2005JD006717, 2006.

Prospero, J. M.: Long-range transport of mineral dust in the global atmosphere: Impact of African dust on the environment of the southeastern United States, Proc. Natl. Acad. Sci. USA, 96, 3396-3403, 1999.

Prospero, J. M., Ginoux, P., Torres, O., Nicholson, S. E., and Gill, T. E.: Environmental characterization of global sources of atmospheric soil dust identified with the NIMBUS 7 Total Ozone Mapping Spectrometer (TOMS) absorbing aerosol product, Rev. Geophys., 40, 1002, doi:10.1029/2000RG000095, 2002.

Pruppacher, H. R. and Klett, J. D.: Microphysics of clouds and precipitation, 361-446, Kluwer academic publishers, The Netherlands, 1997.

Rawls, W. J.: Estimating soil bulk density from particle size analyses and organic matter content, Soil Sci., 135, 123-125, 1983.

Schoonen M. A. A., Cohn, C. A, Roemer, E., Laffers, R., Simon, S.R., and O'Riordan, T.: Mineral-induced formation of reactive oxygen species, in: , Medical Mineralogy and Geochemistry, edited by: Sahai, N. and Schoonen, M. A. A., Rev. Mineral. Geochem., 64, 179-221, 2006.

Shirazi, M. A., Boersma, L., and Johnson, C. B.: Particle size distributions: Comparing texture systems, adding rock, and predicting soil properties, Soil Sci. Soc. Am. J., 65, 300-310, 2001.

Singh, R. P., Prasad, A. K., Kayetha, V. K., and Kafatos, M.: Enhancement of oceanic parameters associated with dust storms using satellite data, J. Geophys. Res., 113, C11008, doi:10.1029/2008JC004815, 2008.

Sokolik, I. and Toon, O.: Incorporation of mineralogical composition into models of the radiative properties of mineral aerosol from UV to IR wavelengths, J. Geophys. Res., 104, 9423-9444, 1999.

Sokolik, I., Toon, O., and Bergstrom, R.: Modeling the radiative characteristics of airborne mineral aerosols at infrared wavelengths, J. Geophys.Res., 103, 8813-8826, 1998.

Tegen, I. and Fung, I.: Modeling of mineral dust in the atmosphere: Sources, transport, and optical thickness, J. Geophys. Res., 99, 22897-22914, 1994.

Tegen, I. and Lacis, A. A.: Modeling of particle size distribution and its influence on the radiative properties of mineral dust aerosol,
J. Geophys. Res., 101, 19237-19244, doi:10.1029/95JD03610, 1996.

Tegen, I. and Kohfeld, K. E.: Atmospheric transport of silicon, in The silicon cycle: Human perturbations and impacts on aquatic systems, edited by: Ittekkot, V., Unger, D., Humborg, C., and Tac An, N., Island Press, Island, (Scope 66), 2006.

Tegen, I., Harrison, S. P., Kohfeld, K., Prentice, I. C., Coe, M., and Heimann, M.: Impact of vegetation and preferential source areas on global dust aerosol: Results from a model study, J. Geophys. Res., 107, 4576, doi:10.1029/2001JD000963, 2002.

Tegen, I., Heinold, B., Todd, M., Helmert, J., Washington, R., and Dubovik, O.: Modelling soil dust aerosol in the Bodélé depression during the BoDEx campaign, Atmos. Chem. Phys., 6, 43454359, doi:10.5194/acp-6-4345-2006, 2006.

Todd, M. C., Washington, R., Martins, J. V., Dubovik, O., Lizcano, G., M'Bainayel, S., and Engelstaedter, S.: Mineral dust emission from the Bodélé Depression, northern Chad, during BoDEx 2005, J. Geophys. Res., 112, D06207, doi:10.1029/2006JD007170, 2007

Todd, M. C., Karam, D. B., Cavazos, C., Bouet, C., Heinold, B., Baldasano, J. M., Cautenet, G., Koren, I., Perez, C., Solmon, F., Tegen, I., Tulet, P., Washington, R., and Zakey, A.: Quantifying uncertainty in estimates of mineral dust flux: An intercomparison of model performance over the Bodele Depression, northern Chad, J. Geophys. Res.-Atmos., 113, D24107, doi:10.1029/2008JD010476, 2008.

Thomson, M. C., Jeanneand, I., and Djingarey, M.: Dust and epidemic meningitis in the Sahel: A public health and operational research perspective, IOP Conf. Ser.: Earth Environ. Sci., 7, 012017, doi:10.1088/1755-1307/7/1/012017, 2009.

Turi, J. L., Yang, F., Garrick, M. D., Piantadosi, C. A., and Ghio, A. J.: The iron cycle and oxidative stress in the lung, Free Radical Bio. Med., 36, 850-857, 2004.

Uno, I., Wang, Z., Chiba, M., Chun, Y. S., Gong, S. L., Hara, Y., Jung, E., Lee, S. S., Liu, M., Mikami, M., Music, S., Nickovic, S., Satake, S., Shao, Y., Song, Z., Sugimoto, N., Tanaka, T., and Westphal, D. L.: Dust model intercomparison (DMIP) study over Asia: Overview, J. Geophys. Res.-Atmos., 111, D12213, doi:10.1029/2005JD006575, 2006.

U.S. Department of Agriculture: State soil geographic (STATSGO) data base-data use information, miscellaneous publication number 1492 (rev. ed.): Fort Worth, Texas, Natural Resources Conservation Service (variously paged), 1994.

Vukovic A., Pejanovic G., Vujadinovic M., Sprigg A. W., Nickovic S., and Djurdjevic V.: Dust Storm of July 5th 2011, Phoenix, Arizona: Numerical Simulation, AGU Fall Meeting, San Francisco, USA, 5-9 December 2011.

Walker, A. L., Liu, M., Miller, S. D., Richardson, K. A., and Westphal, D. L.: Development of a dust source database for mesoscale forecasting in southwest Asia, J. Geophys. Res., 114, D18207, doi:10.1029/2008JD011541, 2009.

Washington, R., Todd, M. C., Engelstaedter, S., Mbainayel, S., and Mitchell, F.: Dust and the low level circulation over the Bodéle Depression, Chad: Observations from BoDEx 2005, J. Geophys. Res., 111, D03201, doi:10.1029/2005JD006502, 2006a.

Washington, R., Todd, M.C., Lizcano, G., Tegen, I., Flamant, C., Koren, I., Ginoux, P., Engelstaedter, S., Goudie, A.S, Zender, C.S., Bristow, C. and Prospero, J.: Links between topography, wind, deflation, lakes and dust: The case of the 
Bodélé Depression, Chad, Geophys. Res. Lett., 33, L09401, doi:10.1029/2006GL025827, 2006b.

WMO: Workshop on modelling and observing the impacts of dust transport/deposition on marine productivity GAW Report No. 202, 46 pp., Geneva, WMO, http://www.wmo.int/pages/ prog/arep/gaw/documents/FINAL_GAW_202_web.pdf, 2011.

Yoshida, S., Hiyoshi, K., Ichinose, T., Nishikawa, M., Takano, H., Sugawara, I., and Takeda, K.: Aggravating effect of natural sand dust on male reproductive function in mice, Reprod. Med. Biol., 8, 151-156, doi:10.1007/s12522-009-0027-8, 2008.
Zender, C. S., Newman, D., and Torres, O.: Spatial heterogeneity in aeolianerodibility: Uniform, topographic, geomorphic, and hydrologic hypotheses, J. Geophys. Res., 108, 4543, doi:10.1029/2002JD003039, 2003.

Zimmermann, F., Weinbruch, S., Schutz, L., Hofmann, H., Ebert, M., Kandler, K., and Worringen, A.: Ice nucleation properties of the most abundant mineral dust phases, J. Geophys. Res., 113, D23204, doi:10.1029/2008JD010655, 2008. 